\title{
OTAK KARAKTER DALAM PENDIDIKAN ISLAM: ANALISIS KRITIS PENDIDIKAN KARAKTER ISLAM BERBASIS NEUROSAINS
}

\author{
Awhinarto, Suyadi \\ Magister Pendidikan Agama Islam, Universitas Ahmad Dahlan \\ awinjanuarpaiuad@gmail.com; suyadi@fai.uad.ac.id.
}

\begin{abstract}
Abstrak: Penelitian ini bertujuan menganalisis pendidikan karakter dalam perspektif neurosains. Hal ini dilatarbelakangi oleh bukti adanya hubungan yang tak terpisahkan antara otak dan karakter manusia. Oleh karena itu, pendidikan karakter sebenarnya tidak dapat dipisahkan dari organ penting manusia yang biasa disebut dengan otak. Penelitian ini merupakan studi kepustakaan dengan pendekatan kualitatif. Sumber data penelitian ini adalah berbagai literatur baik berasal dari buku maupun jurnal terkait dengan pendidikan karakter dan neurosains. Pengumpulan data dilakukan dengan penelusuran dan pembacaan referensi terkait baik secara manual maupun digital. Data yang terkumpul kemudian didisplay, direduksi, dan dikonstruksi menjadi konsep baru yang utuh. Analisis data dilakukan secara induktif dengan mengedepankan intelektualitas. Hasil penelitian menunjukkan otak manusia berfungsi mempengaruhi manusia dalam menjalankan aktivitasnya. Perilaku manusia dikontrol oleh sistem saraf dalam otak, sehingga seluruh aktivitasnya bermuara pada fungsi otaknya. Pendidikan karakter Islam menekankan pada proses pembentukan perilaku manusia yang baik (al-akhlaqul karimah) dan menjauhkan manusia dari perilaku buruk (al-akhlaqul madzmumah). Nilai-nilai karakter dalam pendidikan Islam didasarkan pada nilai-nilai kebaikan (ihsan) yang terkandung dalam Alquran dan hadis Nabi Muhammad saw.
\end{abstract}

Kata kunci: Otak, pendidikan Islam, pendidikan karakter, neurosains.

\section{CHARACTER BRAIN IN ISLAMIC EDUCATION: CRITICAL ANALYSIS OF ISLAMIC CHARACTER EDUCATION BASED ON NEUROSAINS}

\begin{abstract}
This study aims to analyze character education in the neuroscience perspective. This is motivated by evidence of an inseparable relationship between the brain and human character. Therefore, character education actually cannot be separated from important human organs commonly called the brain. This research is a literature study with a qualitative approach. The data source of this research is a variety of literature both from books and journals related to character education and neuroscience. Data collection was done by searching and reading related references both manually and digitally. The collected data were then displayed, reduced, and constructed into a whole new concept. Data analysis was carried out inductively by promoting intellect. The results showed that the human brain functions were to influence humans in carrying out their activities. Human behavior is controlled by the nervous sistem in the brain, so that all of his activities lead to the functioning of the brain. Islamic character education
\end{abstract}


emphasizes the process of forming good human behavior (al-akhlaqul karimah) and keeping people from bad behavior (al-akhlaqul madzmumah). Character values in Islamic education are based on the values of goodness (ihsan) contained in the Qur'an and the traditions of the Prophet Muhammad PBUH.

Keywords: Brain, Islamic education, character education, neuroscience.

\section{PENDAHULUAN}

Neurosains merupakan ilmu neural atau juga sering disebut sebagai neural science yang mempelajari sistem saraf, terutama mempelajari sel saraf atau neuron dengan cara pendekatan multidisipliner (Pasiak, 2010). Pada umumnya neurosains merupakan cabang dari ilmu biologi yang kemudian berkembang sampai merambat ke berbagai cabang ilmu pengetahuan lainnya, seperti psikologi, biokimia, fisiologi, farmakologi, informatika, ilmu komputer, statistika, fisika, dan kedokteran. Tujuan dari neurosains yaitu mempelajari dasar suatu biologis dari setiap perbuatan perilaku manusia. Artinya, tugas yang paling utama dari bidang ilmu neurosains yaitu menjelaskan perilaku manusia dari sudut pandang aktivitas yang ada di dalam otaknya.

Penelitian terakhir dalam bidang ilmu neurosains menemukan beberapa bukti yang menjelaskan hubungan yang tidak terpisahkan antara otak manusia dan perilaku (karakter) seorang manusia (Firmanzah, 2012). Melalui instrumen Positron Emission Tomography (PET) dapat dilihat bahwa ada sejumlah enam sistem otak yang secara terpadu meregulasi semua perilaku manusia dalam kehidupannya. Keenam sistem tersebut memiliki peran sangat penting dalam pengaturan kognisi, afeksi, dan psikomotorik yang di dalamnya termasuk IQ, EQ, dan SQ (Suyadi, 2012). Hal ini menjadikan bukti bahwa pendidikan karakter sejatinya mengembangkan potensi otak manusia, semua sistem yang ada di otak secara bersama membangun sikap dan perilaku manusia. Oleh sebab itu, meregulasi kinerja otak secara normal akan menghasilkan fungsi yang optimal sehingga perilaku manusia dapat dikontrol secara sadar dengan melibatkan beberapa dimensi emosional dan spiritual. Dengan demikian, pendidikan karakter dapat dijelaskan dalam mekanisme kerja otak pada tingkat molekulnya, khususnya enam sistem kerja pada otak (Suyadi, 2017).

Sebagai contoh, berikut laporan kasus yang dibuat oleh Dr. John Harlow dan kemudian dipelajari secara mendalam oleh Dr. Antonio Damasio, yang memberikan bukti ilmiah bagaimana kaitan erat antara kondisi otak dengan sikap dan perilaku pada manusia. Pada tahun 1848, Phineas Gage merupakan seorang lelaki insinyur bangunan, berusia 25 tahun yang bekerja untuk perusahan pembuat kereta api Rutland \& Burlington Railroad. Menurut pimpinannya, Gage merupakan seorang pekerja yang amat cakap dan cermat. Ia seorang lelaki yang efisien dan 
sangat cocok untuk pekerjaan yang membutuhkan ketangkasan fisik, ketahanan stamina dan daya konsentrasi yang tinggi untuk jangka waktu lama. Tugas utama Gage adalah membuka jalan baru kereta melintasi Vermont. Suatu waktu, karena adanya bebukitan dan gunung yang sulit ditembus dengan cara biasa, Gage mengambil keputusan untuk meledakkan gunung dan bukit batu itu sehingga lebih efisien dan mudah ditembus. Caranya, dengan membuat lubang di batu, diisi separuh bubuk mesiu, sumbu dipasang dan ditutupi rapat dengan pasir. Setelah lubang menjadi padat kemudian sumbu akan dinyalakan. Karena Gage adalah insinyur ahli di bidang ini, maka ia tak mengalami kesulitan. Persis ketika lubang terakhir diisi mesiu dan belum sempat dimasukkan pasir, tiba-tiba seseorang memanggilnya namanya dan membuat Gage menoleh melalui bahu kanannya dalam sepersekian detik, tanpa sadar batang besi yang dipegang Gage terisi dalam lubang dan membuat gesekan dengan bubuk mesiu, terjadilah ledakan yang sangat dahsyat yang membuat kaget semua orang. Ketika kekagetan hilang semua orang mendapati sebatang besi baja telah menancap di kepala Gage. Besi itu masuk melalui pipi kiri Gage menembusnya menuju otak bagian depan dan keluar di ubunubun kepala. Seketika Gage di bawa ke satu tempat untuk melepaskan batangan baja itu. Dokter yang datang kemudian menemukan adanya lubang seperti terowongan di ubun-ubun Gage. Jika terowongan ini dilihat dari ubun-ubun, maka akan tembus hingga tulang pipi dan tampak ada sedikit cahaya. Gage masih tampak sehat dan rasional menceritakan kisah kronologis kejadian itu. Ia kemudian dirawat dan dinyatakan sembuh dalam waktu 2 bulan usai kejadian.Namun, apa yang terjadi? Gage kini bukanlah Gage yang dulu. Ia berubah total, meski tetap cerdas Gage kehilangan kepribadiannya yang asli. Ia mengalami kekacauan dalam hidup, berpindah-pindah kerja dan bergantung pada orang lain kehilangan kesantunan sosial dan perencanaan masa depan (Damasio, 1994).

yang merupakan pusat dari pergerakan yang dilakukan oleh manusia. Sebagai bagian terpenting dari manusia, tentu otak memiliki peran yang sangat besar bagi manusia (Timotius, 2018). Karena pentingnya peran otak ini bagi manusia, tentu otak harus menjadi perhatian penting terutama untuk halhal penting yang dilakukan manusia, misalnya dalam hal pendidikan dan pembelajaran. Di sinilah pentingnya permasalahan otak dalam pendidikan. Dalam penelitian ini akan dikaji lebih mendalam bagaimana peran dan fungsi otak bagi manusia. Lebih khusus lagi bagaimana otak dijadikan dasar untuk pendidikan karakter yang dilakukan oleh pendidik agar pendidikan yang dilakukan berhasil seperti yang diharapkan. Penelitian ini berusaha mengkaji permasalahan tersebut dalam perspektif Islam.

\section{METODE}

Penelitian ini merupakan penelitian kualitatif yang didasarkan pada kajian kepustakaan, yaitu serangkaian penelitian yang 
berkenaan dengan cara pengumpulan data kepustakaan (jurnal ilmiah, dokumen, buku, artikel dll) (Sukmadinata, 2009). Penekanan penelitian ini pada bagaimana menemukan berbagai teori, dalil, hukum, prinsip, atau gagasan yang dapat digunakan dalam proses menganalisis serta memecahkan masalah yang diteliti (Sarjono, 2008). Adapun sifat dari penelitian ini adalah deskriptif analisis yaitu penguraian secara teratur seluruh konsep kemudian pemberian pemahaman dan penjelasan dari hasil yang menjadi objek deskripsi. Penelitian ini juga menggunakan proses pendekatan filosofis dan pedagogis. Dengan filosofis ini, pemecahan masalah diselidiki secara rasional melalui sebuah penalaran yang terarah sehingga mendapat hasil yang terbaik.

Teknik pengumpulan data yang penulis lakukan dalam penelitian ini dengan mencari dan mengumpulkan data yang menjadi sumber-sumber pelenitian. Setelah data tersebut terkumpul, langkah selanjutnya adalah melakukan penelaahan dalam hubungannya dengan masalah yang diteliti, sehingga memperoleh data dan bahan untuk penelitian. Data yang terkumpul kemudian dianalisis secara kualitatif dengan menggunakan cara berpikir induktif.

\section{HASIL DAN PEMBAHASAN \\ Peran Otak Karakter dalam Pendidikan}

Positron

Emission

Tomography (PET) adalah suatau teknologi pertama yang digunakan dalam mengobservasi berbagai macam fungsi otak dengan cara menyuntikkan cairan radioaktif dalam subjek tempat cairan tersebut akan bersirkuit ke dalam otak. Wilayah yang bereaksi lebih tinggi akan memperoleh akumulasi yang lebih banyak radiasi yang dalam proses ini ditangkap oleh cincin detektor yang dipasangkan pada sekitar area kepala subjek (pasien). Selanjutnya, komputer akan menampilkan konsentrasi radiasi sebagai gambar aliran darah yang tampak pada irisan melintang di wilayah otak yang sejajar dengan cincin detektor, area otak yang lebih aktif berwarna merah dan kuning, sedangkan area otak yang lebih pasif berwarna biru dan hijau. Teknologi ini sekarang dilarang khususnya untuk anak-anak sehat, dikarenakan tingginya radiasi yang ditimbulkan (Suyadi, 2017).

Neuroplastisitas adalah daya pembentukan sirkuit sel saraf (melalui kemampuan sel saraf untuk berubah) oleh pengalaman. Hal ini menunjukkan bahwa manusia diberikan potensi untuk terus berubah di sepanjang hidupnya, lebih singkat bahwa neuroplastisitas merupakan kemampuan otak untuk memodifikasi dirinya (sel saraf) dan beradaptasi dengan tantangan yang berasal dari lingkungan. Neuroplastisitas memungkinkan setiap orang bisa menjadi apa saja seperti yang diharapkan melalui latihan dan pengalaman. Sebagai contoh salah seorang yang ingin dirinya menjadi manusia yang cerdas tentu ia akan belajar dengan giat dan sungguh-sungguh agar dapat mencapai hasil yang dimaksimalkan. Jika hal ini dilakukan dengan terus menerus maka ia akan menjadi karakter atau perilaku yang baik, 
sehingga otak manusia pun akan berkembang dengan baik.

Sifat neuroplastisitasnya yaitu hubungan antarsel saraf otak yang biasa disebut dengan sinapsis. Hal ini sangat rentan berubah dalam pelbagai intervensi yang merupakan sifat dasar otak manusia yang membuatnya dapat berubah pada tingkat seluler atau molekuler. Sifat ini juga yang dapat membuat upayaupaya dalam pembentukan hal-hal baik. Hal tersebut yang ada kaitannya dengan moral dan menjadi hal yang tidak mudah. Pelatihan moral (moral training) sejak dini dan berulang menjadi sangat esensial. Kebiasaankebiasaan yang tidak baik, seperti halnya meminum minuman keras, merampok, berjudi, seks tidak wajar, dan semua jenis perbuatan tercela lainnya dengan cepat dapat mengubah otak melalui pembentukan suatu sirkuit yang baru. Jika hal ini terjadi secara berulang-ulang dan terus menerus, maka akan segera membentuk struktur tetap di dalam otak yang sangat sulit diubah. Demikian halnya dengan pembiasaan melakukan hal-hal baik. Oleh sebab itu, pembiasaan yang baik tentu harus ditanamkan sejak dini sehingga otak akan berpengaruh sesuai dengan aktivitas atau perilaku yang dilakukan.

Seorang ilmuan yang membahas ilmu tentang neurosains membuktikkan bahwa sel saraf otak mempunyai suatu kemampuan untuk melahirkan sel saraf baru. Nama lain dalam hal tersebut dikenal dengan sebutan neurogenesis. Selain itu, bukti lain menjelaskan adanya sel saraf yang mempunyai kemampuan adaptasi serta dapat melakukan perubahan struktur berdasarkan pengalaman yang dapat diterima oleh lingkungannya. Pengalaman hidup seseorang dapat mengubah struktur otak seorang manusia. Hal ini dikenal dengan sebutan neuroplastisitas sel saraf (Begley, 2007). Dua pendekatan tersebut yakni neurogenesis dan neuroplastisitas mampu menerangkan bagaimana sikap dan perilaku seseorang dalam sehari-hari bisa berubah berdasarkan pengalaman atau kebiasaan hidup yang dilaluinya. Sebagai contoh, jika ada seorang purnawirawan jendral yang semasa menjabat sebagai prajurit, maka dia akan cenderung konservatif dalam sikap pemikirannya. Hal ini disebabkan karena budaya yang sudah melekat di dalam dunia militer sehingga menjadi sebuat karakter kepribadian yang sangat kuat. Oleh sebab itu, jarang sekali terlihat seorang pernawirawan jendral yang menjabat di sebuah jabatan politik pemerintahan atau birokrasi yang terkesan otoriter dan kaku untuk bisa bersikap baik, bijaksana, dan arif mau mengajak bermusyawarah serta dapat menerima pendapat orang lain (Suadu, 2018).

Kaum konservatif menunjukan bahwa sistem kognisi cenderung lebih keras dari pada bersikap lemah lembut, sedangkan kaum liberal akan lebih cenderung responsif dengan kompleksitas informasi yang menunjukkan rasa semangat pembaharu (Amodio \& Yee, 2007). Pendapat tersebut dikuatkan dengan adanya suatu pemetaan terhadap otak dengan menggunakan suatu alat yang digunakan untuk pencitraan otak (brain imaging) guna melihat suatu perubahan-perubahan pada 
struktur serta aktivitas yang terjadi di area right amygdala (sesuatu yang berperan dalam mengatur emosi seseorang) dan anterior cingulate (sesuatu yang berperan dalam fungsi adaptasi, mempunyai gagasan, dapat mengalihkan perhatian serta dapat melihat pilihan, kemampuan untuk bekerja sama) (Kanai, Feilden, Frith, \& Rees, 2011). Hasilnya menunjukkan bahwa otak bagi kaum konservatif lebih dominan dikendalikan oleh area amygdala, sedangkan otak kaum liberal akan cenderung lebih kuat dipengaruhi area anterior cingulate.

Otak merupakan suatu bagian yang penting pada manusia. Hal ini dikarenakan otak adalah suatu perangkat yang mempunyai fungsi untuk menentukan suatu esensi seseorang sebagai khalifah di muka bumi (Q.S. al-Baqarah: 30). Di samping itu, otak juga dapat menjalankan peranan yang amat penting dalam melakukan survivalitas, pengatur reflek, berpikir, melakukan nalar kritis, mengatur emosi, melatih akal sehat, kesadaran, bahkan dalam mengambil sebuah keputusan. Oleh sebab itu, otak bukanlah materi atau benda seperti benda pada umumnya yang dikenal banyak orang. Sepanjang otak itu hidup, maka ia akan menjadi living machine bagi seseorang. Meski berstuktur layaknya sebuah mesin, otak merupakan mesin yang hidup, mesin yang dapat memperbaharui dirinya sendiri, dan mesin yang justru dapat menjadi lebih bagus jika semakin lama dipakai, kecuali strukturnya yang dapat dikenali sebagai mesin dan sifat-sifat mesin sebagaimana didapati pada mesin-mesin yang pernah dibuat oleh manusia. Otak dan sistem saraf dibangun dan diukir sedemikian rupa sel demi sel sepanjang interaksinya dengan lingkungan dan pemrograman genetik. Otak memiliki kemampuan adaptasi yang canggih sehingga ia berkembang sejalan dengan perubahan yang dialaminya. Otak adalah organ yang use dependent development. Kemampuan otak untuk menyimpan semua memori dan hasil belajar manusia memungkinkannya menjadi organ yang sangat menentukan manusia sebagai manusia yang sejatinya (Cozolino, 2002).

Berkaitan dengan sifat use dependent development, otak dengan pemrograman genetika ada pada dua fungsi gen; pertama fungsi template dan kedua fungsi transcription. Fungsi template yaitu fungsi yang tidak memungkinkan gen dipengaruhi oleh lingkungan. Sedangkan fungsi transcription yaitu fungsi yang dapat memungkinkan pengaruh lingkungan terhadap perubahan gen. Organisasi otak dalam bentuk triune brain dan refleksi-refleksi dasar masuk dalam fungsi template yang fungsinya dimiliki oleh semua anggota spesies. Ekspresi gen untuk jenis ini relatif tidak bisa dipicu oleh lingkungan. Sedangkan fungsi transcription, ekspresinya dipengaruhi oleh adanya picuan dari lingkungan. Fungsi transkripsi ini memengaruhi bagaimana ekspresi zat pembawa pesan saraf (neurotransmitter) pada berbagai bagian otak. Kerjanya melalui serangkaian proses biokimiawi dan aktivasi sel saraf yang terjadi secara spesifik. Sebagai contoh, dari riset yang pernah 
dilakukan, meskipun sepasang kembar identik dibesarkan di rumah yang sama dan memiliki gen yang identik untuk penyakit jiwa skizofrenia, tetapi hanya satu saja yang mengalami penyakit ini. Interaksi unik dan spesifik orang demi orang akan memicu fungsi transkripsi ini yang menghasilkan ekspresi spesifik juga. Fungsi transkripsi gen inilah yang memiliki kaitan erat dengan sifat neuroplastisitas otak (Cozolino, 2002).

Baik fungsi template maupun transcription dari gen memungkinkan untuk dipahami bagaimana sebenarnya otak bereaksi terhadap lingkungan sekitar. Fasefase perkembangan dan pematangan komponen otak berlangsung di seluruh sistem otak dengan masa dan Tabel 1. Sistem Otak Manusia waktu yang berbeda-beda. Otak tidak berkembang secara serempak dan sekaligus sehingga perhatian terhadap waktu-waktu khusus menjadi sangat penting. Ini berkaitan dengan pembentukan karakter saat dewasa. Riset dengan instrument PET (positron emission tomography) menemukan balat pencitra otak dengan mengukur aktivitas metabolik otak dengan molekul radioaktif dan diketahui bahwa terdapat eman sistem otak yang bekerja untuk tugas spesifik, tetapi saling terhubungan. Eman sistem itu adalah: cortex prefrontalis, lobus temporalis, sistem limbik, gyrus cingulatus, ganglia basalis, dan cerebellum yang secara jelas disajikan dalam tabel 1 di bawah ini.

\begin{tabular}{|c|c|c|c|}
\hline No. & Sistem Otak & Fungsi & Gangguan \\
\hline 1. & $\begin{array}{l}\text { Cortex } \\
\text { prefrontal }\end{array}$ & $\begin{array}{l}\text { Atensi, planning, ketaan pada } \\
\text { aturan, inhibisi, empati, } \\
\text { kendali impuls, moralitas, } \\
\text { etika dan organisasi }\end{array}$ & $\begin{array}{l}\text { Kehilangan kejernihan } \\
\text { berpikir, inatensi, impulsif, } \\
\text { prokrastinasi, kehilangan } \\
\text { empati, kehilangan etika, } \\
\text { disorganisasi }\end{array}$ \\
\hline 2. & $\begin{array}{l}\text { Sistem } \\
\text { limbik }\end{array}$ & $\begin{array}{l}\text { Control mood, motivasi, sikap, } \\
\text { tidur/makan, keterikatan, } \\
\text { pembauan, libido }\end{array}$ & $\begin{array}{l}\text { Depresi, miskin motivasi, poor } \\
\text { attitude, gangguan } \\
\text { tidur/makan, kehilangan } \\
\text { pembauan, mengisolasi diri, } \\
\text { rasa tidak nyaman, kehilangan } \\
\text { harapan }\end{array}$ \\
\hline 3. & $\begin{array}{l}\text { Ganglia } \\
\text { basalis }\end{array}$ & $\begin{array}{l}\text { Perasaan tenang, metana level } \\
\text { kecemasan, penghindaran } \\
\text { konflik, pengaruh pergerakan, } \\
\text { mediasi kesenangan dan } \\
\text { motivasi }\end{array}$ & $\begin{array}{l}\text { Ketegangan, nervous, } \\
\text { cemas/panik, berpikir buruk, } \\
\text { tremor, adiksi, kehilangan } \\
\text { motivasi }\end{array}$ \\
\hline 4. & $\begin{array}{l}\text { Cyrus } \\
\text { cingulatus }\end{array}$ & $\begin{array}{l}\text { Brains's gear shifter, } \\
\text { fleksibelitas kognisi, kerja } \\
\text { sama, memilih, deteksi } \\
\text { masalah }\end{array}$ & $\begin{array}{l}\text { Kuatir, kaku, kompulsif, } \\
\text { obsesif, mendendam, tak bisa } \\
\text { mendeteksi kesalahan } \\
\text { konseling hubungan } \\
\text { interpersonal }\end{array}$ \\
\hline 5. & Lobus & Valensi emosional, stabilitas & Reaksi emosional, tidak peka \\
\hline
\end{tabular}




\begin{tabular}{cll}
\hline temporalis & $\begin{array}{l}\text { emosi, kendali watak, memori, } \\
\text { bahasa pendengaran, membaca } \\
\text { jejak sosial, pengalaman } \\
\text { spiritual, rekognisi ekspresi } \\
\text { fasial }\end{array}$ & $\begin{array}{l}\text { rangsang, moodiness, marah, } \\
\text { panik, takut, fobio, pikiran } \\
\text { negatif, mudah lupa, kesulitan } \\
\text { mengemukakan kata, } \\
\text { kehilangan, keterampilan } \\
\text { sosial, gangguan menjejaki } \\
\text { ekspresi wajah }\end{array}$ \\
\hline 6. Cerebellum & $\begin{array}{l}\text { Kontrol gerak, postur, dan } \\
\text { gaya berjalan, fungsi eksekutif } \\
\text { kecepatan integrasi kognitif }\end{array}$ & $\begin{array}{l}\text { Gangguan koordinasi, pikiran } \\
\text { melambat, bicara melambat, } \\
\text { impulsif, sulit belajar, } \\
\text { disorganisasi }\end{array}$ \\
\hline
\end{tabular}

Sumber: Amin, 1998.

Jika diamati tabel 1 di atas dengan seksama bagaimana fungsi, disfungsi, dan intervensi terapetik enam sistem otak, jelaslah bahwa semua sistem dalam otak bekerja bahu-membahu untuk saling membangun sikap dan perilaku manusia. Mempertahankan penuh terhadap kinerja otak yang secara alami atau normal akan menghasilkan suatu fungsi yang optimal dari otak.

Riset-riset tentang ilmu neurosains saat ini lebih banyak memberi perhatian bagaimana halhal yang disebut 'tidak logis'. Contohnya adalah seperti rasa cinta, empati, kecakapan sosial, pelbagai contoh semacam emosi, bahkan halhal yang bersifat mistis-religius. Hal yang kerap dikategorikan 'tidak logis' itu artinya tidak dapat diproses secara sadar dan menggunakan pikiran yang ternyata merupakan kegiatan yang tidak berbeda dengan kegiatan-kegiatan logis. Hal-hal logis yang secara umum disebut sebagai 'knowledge' (pengetahuan) memiliki kesamaan pada tingkat molekuler otak dengan hal-hal yang disebut 'character' (perilaku). Keduanya, terjadi pada sinapsis dan menggunakan neurotransmitter (zat pembawa pesan di dalam sistem saraf) yang bisa sama. Dalam kurun waktu hampir 20 tahun terakhir banyak temuan riset yang menguatkan argumen yang menjelaskan metabolisme terhadap fisik seseorang pada otak yang memainkan peranan penting dalam membentuk pikiran serta emosi manusia (Tancredi, 2005).

Sifat neuroplastisitas menunjukkan adanya suatu hubungan yang terjadi pada sel saraf otak yang disebut dengan sinapsis. Hal ini menjelaskan sifat yang rentan untuk berubah terhadap pelbagai intervensi yang merupakan sifat-sifat dasar pada otak yang dapat berubah pada tingkat seluler bahkan pada tingkat molekuler. Sifat-sifat inilah yang membuat upaya dalam pembentukan suatu hal yang amat baik. Sesuatu yang berkaitan dengan moral menjadi suatu hal yang tidak mudah. Pelatihan moral (moral training) sejak dini dan berulang menjadi sangat esensial. Kebiasaankebiasaan yang amat buruk, seperti halnya minum-minuman keras (mabuk), merampok, melakukan seks bebas, dan semua jenis perbuatan buruk lainnya dengan cepat mampu mengubah otak melalui pembentukan-pembentukan sirkuit baru yang jika hal ini terjadi secara berulang-ulang dan terus-menerus 
akan membuat suatu struktur yang tetap pada otak yang akan semakin sulit diubah. Demikian halnya dengan pembiasaan melakukan halhal yang baik (Tancredi, 2005).

Fakta ilmiah tersebut memberikan pelajaran penting bahwa melakukan sebuah kebaikan secara berulang-ulang, apalagi dengan penguatan secara sistematis, akan dapat mengubah struktur otak pada tingkat sinaps. Ketika melakukan suatu kebaikan, tentu otak akan merangsang dengan baik yang akhirnya akan membentuk sirkuit baru jika dilakukan secara terusmenerus kegiatan yang baik tersebut, sehingga karakter yang nanti akan terbentuk secara permanen adalah karakter yang baik pada diri manusia. Ada delapan komponen karakter yang melekat pada diri manusia seperti berikut ini. Pertama, trustworthiness, dengan indikator: memiliki integritas yang tinggi, berlaku jujur, serta loyalitas yang tinggi. Kedua, fairness, dengan indikator: mempunyai keterbukaan dan sikap yang adil. Ketiga, caring, dengan indikator: mempunyai rasa empati serta rasa kasih dan saying. Keempat, respect, dengan indikator: mampu menghargai serta mampu menghormati orang lain. Kelima, citizenship, dengan indikator: mampu berlaku sadar terhadap suatu hukum dan sadar akan adanya suatu budaya. Keenam, responsibility, dengan indikator: memiliki tanggung jawab yang baik serta disiplin waktu. Ketujuh, positive emotions, dengan indikator: mempunyai rasa keihklasan, dapat bersyukur, dan mempunyai rasa kesabaran yang tinggi. Kedelapan, innovation, dengan indikator: memiliki kreativitas dan rasa yang optimis. Jika delapan pilar karakter tersebut dilatih secara berulang-ulang, sistematis, dinamis, dan diberi suatu penguatan, maka akan mampu mengubah suatu struktur sinaps pada otak manusia. Pembentukan memori dan aktivitas belajar akan menjadi dampak yang besar karena memiliki esensi yang baik. Pembentukan koneksi baru dan penguatan sinaps pada otak terjadi dikarenakan proses belajar yang dilakukan secara terusmenerus dalam pembentukan struktur memori yang dilakukan secara langsung dengan waktu yang tepat (Kandel, 2006).

\section{Pendidikan Karakter Islami}

Pendidikan mempunyai definisi yang sangat luas, mencakup segala perbuatan atau usaha yang dilakukan seseorang agar lebih baik. Banyak ahli mendefinisikan pendidikan namun dalam pembahasan mengalami beberapa kesulitan dikarenakan antarsatu pengertian dengan pengertian yang lain sering terjadi perbedaan. Pendidikan dipahami sebagai mendidik atau membimbing secara sadar oleh seorang pendidik terhadap suatu perkembangan anak didik atau peserta didik, baik rohani bahkan jasmaninya sekalipun, sampai memperoleh terbentuknya suatu kepribadian yang paling utama (Ramdhani, 2017; Zuchdi et al., 2011; Marimba, 1989). Pengertian ini meskipun begitu sederhana tetapi secara substansial mampu mencerminkan suatu proses dalam pendidikan. Menurut pengertian ini, pendidikan dibatasi pada pengembangan seorang anak didik oleh seorang pendidik. 
Pendidikan merupakan jalan dan proses untuk membentuk suatu kecakapan yang fundamental melalui emosional dan intelektual untuk berinteraksi dengan sesama manusia dan alam semesta. Tujuan pendidikan ialah agar para generasi pemuda mampu meneruskan generasi yang tua yang dapat memahami, menghayati, dan mengamalkan nilai-nilai dengan cara mewariskan suatu pengalaman yang dimiliki, keterampilan, dan kemampuan yang melatarbelakangi nilai-nilai kehidupan mereka (Muslich, 2011). Mangun Budiyanto (2010) mendefinisikan pendidikan sebagai usaha dalam mempersiapkan serta menumbuhkembangkan anak didik yang prosesnya berlangsung terus menerus semenjak ia lahir sampai meninggal. Aspek-aspek yang disiapkan dan ditumbuhkan meliputi aspek rohani, akalnya, badannya, tanpa mengesampingkan dan melebihkan salah satu aspek yang lain, persiapan, pertumbuhan, dan perkembangan yang diarahkan agar menjadi lebih baik.

Dari definisi-definisi tentang pendidikan di atas, dapat disimpulkan bahwa pendidikan merupakan usaha seluruh aktivitas yang dilakukan secara sadar oleh pendidik kepada peserta didik dengan penuh rasa tanggung jawab agar diperoleh perkembangan yang baik bagi rohani dan jasmani, baik secara formal maupun informal, dan secara terus-menerus sehingga tercipta kebahagiaan. Oleh karena itu, pendidikan harus dilaksanakan dengan baik dan benar, yakni dengan perencanaan yang benar, dilakukan dengan metode pembelajaran yang baik dan sesuai, serta dievaluasi secara terus-menerus untuk mendapatkan kepastian apakah pendidikan yang dilaksanakan berhasil atau tidak.

Selanjutnya perlu dikaji tentang karakter. Istilah karakter merupakan terjemah dari kata berbahasa Inggris 'character' (Echols \& Shadily, 2006). Kata karakter ini berasal dari kata Yunani, charassein, yang berarti tajam atau kedalam (Bagus, 2005). Menurut Haedar Nashir (2013) karakter sering dikaitkan dengan kepribadian seseorang. Sedangkan Muchlas Samani (2011) menegaskan bahwa karakter merupakan cara berperilaku dan berpikir yang memiliki ciri khas di setiap individu baik untuk bekerja sama atau hidup, baik di lingkungan masyarakat maupun keluarga. Tentu masih banyak pendapat lain tentang karakter yang dikemukakan oleh para ahli, baik dari Indonesia maupun dari luar Indonesia (Marzuki, 2015; Zuchdi et al., 2011; Frye et al., 2002; Ryan \& Bohlin, 1999; Lickona, 1991).

Karakter sering mengacu dalam serangkain sikap (attitudes), keterampilan (skills), motivasi (motivations), dan perilaku (behaviors). Karakter meliputi sikap kritis, perilaku seperti bertanggung jawab, jujur, dan mempertahankan prinsip-prinsip moral dalam keadaan yang penuh dengan ketidakadilan. Karakter atau akhlak dijelaskan sebagai nilai-nilai atau norma-norma perilaku seseorang yang mempunyai hubungan secara langsung dengan Tuhan Yang Maha Esa, sesama manusia, kepada diri sendiri, terhadap lingkungan sosial, dan terhadap kebangsaan yang akan terwujud dalam suatu sikap, perilaku, 
pikiran, dan perasaan yang tentunya berdasarkan nilai-nilai, tata krama, budaya, hukum serta adat dan istiadat (Anita \& Kartowagiran, 2019; Fitri, 2018; Febrianshari \& Ekowati, 2018; Marzuki, 2015).

Karakter manusia akan terbentuk melalui pengulangan terhadap perilaku-perilaku tertentu. Karakter juga terbentu melalui perbuatan yang menanggapi suatu keadaan yang sering diucapkan terhadap orang lain. Karakter menjadi suatu kebiasaan dan secara langsung menempel pada seseorang sehingga dia tidak menyadari karakter dirinya. Oleh karena itu, orang akan lebih mudah menilai karakter orang lain.

Dari beberapa definisi tentang karakter dapat disimpulkan bahwa karakter merupakan kekuatan mental seseorang yang diupayakan terbentuk sehinggal menghasilkan suatu watak yang menjadi ciri khusus baginya. Pendidikan karakter merupakan pendidikan moral dan budi pekerti yang mencakup ilmu pengetahuan yang dimiliki, melalui perasaan, dan tindakan dilakukannya.

Dirkusus pendidikan karakter akan memberikan pesan bahwa nilainilai keagamaan dan spiritual tidak akan bisa dipisahkan dengan pendidikan karakter. Moralitas serta nilai spiritual merupakan hal yang sangat fundamental, sehingga tanpa keduanya pembangunan kesejahteraan manusia atau organisasi sosial manapun dapat dipastikan akan lenyap. Islam adalah agama rahmatan lil 'alamin (Q.S. alAnbiya': 107). Islam tidak mengajarkan bahwa ilmu terpisah dari etika, moral, dan karakter. Islam sangat mementingkan komparasi antara wahyu dan akal pikiran dalam menentukan sebuah nilai moral yang terbuka untuk diperdebatkan. Dalam Islam terdapat tiga nilai-nilai yang utama, yaitu: akhlak, adab, dan keteladanan (Setiawan, 2014).

Pendidikan karakter Islami harus dikembangkan melalui perilaku yang baik agar dapat menjadi contoh perilaku bagi umat manusia. Oleh karena itu, pendidikan agama Islam menjadi sentral untuk pendidikan karakter karena di dalamnya diajarkan tentang kebaikan di dunia akhirat, bagaimana memperoleh kebaikan tersebut dan bagaimana menjalankan dan mengamalkannya dalam kehidupan sehari-hari. Inti dari kebaikan dalam pendidikan Islam adalah takwa, yakni menjalankan segala perintah Allah Swt. dan menjauhi segala larangan-Nya (Majid \& Andayani, 2017).

Hal yang terpenting dalam pendidikan karakter Islam adalah pendidikan yang berporos pada moralitas seseorang sebagai pondasi awal dalam membentuk akhlak yang baik (karakter/perilaku) sehingga dapat diaplikasikan dengan sebaik mungkin. Islam menempatkan Nabi Muhammad saw. sebagai teladan atau model agung bagi semua umat Islam dalam bersikap dan berperilaku sehari-hari dalam berbagai aspek kehidupan mereka.

Dengan memperhatikan pentingnya peran otak bagi manusia dalam praksis pendidikan, termasuk pendidikan Islam, maka pendidikan karakter dalam Islam harus berusaha menjadikan otak sebagai pusat dalam melakukan pendidikan dan pembelajaran. Kebaikan merupakan suatu nilai tertinggi yang harus dituju 
dalam pendidikan Islam, di samping kebenaran. Meraih kebaikan tidak semudah meraih kebenaran, karena kebenaran dapat dipelajari dengan mudah dan secara tepat, tetapi kebaikan harus diperoleh melalui proses panjang, yakni melalui pembiasaan yang terus-menerus dan berulang-ulang. Pemikiran yang benar dan ditopang pembiasaan berbuat baik menjadikan mengantarkan pada struktur otak yang baik pula. Dengan pembiasaan karakter-karakter baik secara berulang-ulang otak manusia akan terangsang untuk terus merekamnya dengan kuat, sehingga dapat mendorongnya untuk mengulang-ulangnya karakter tersebut sampai akhirnya menjadi permanen.

\section{PENUTUP}

Otak merupakan organ manusia yang sangat penting, sehingga dalam pengaturannya otak memiliki fungsi yang banyak memberikan pengaruh pada tingkah laku atau perilakunya. Perilaku manusia pada dasarnya dikontrol oleh sistem saraf dalam otak, sehingga seluruh perilaku yang dilakukan oleh manusia sejatinya bermuara pada fungsi otak yang bekerja penuh untuk memberikan stimulus terhadap suatu rangsangan yang dilakukan. Semua hal yang berpotensi meningkatkan kinerja otak harus dipandang sebagai bagian penting. Salah satu cara yang dapat meningkatkan kualitas otak manusia ialah dengan proses pendidikan yang mengarah pada tingkah laku yang dalam hal ini adalah proses pendidikan karakter. Fungsi pendidikan karakter sejatinya mengajarkan pada proses perilaku yang baik (al-akhlaqul karimah). Islam mengajarkan perilaku-perilaku yang baik kepada seluruh umat manusia dengan mengacu pada Alquran dan sunnah. Bahkan, pendidikan karakter merupakan inti dari pendidikan Islam.

Manusia yang mampu memahami hubungan yang baik antara otak, sikap, dan perilakunya dikategorikan sebagai manusia yang normal. Dalam segala aktivitasnya, dia akan mampu melakukan kontrol diri melalui kesadaran akan fungsi otak yang mengontrol enam sistem yang bekerja dalam dirinya. Pendidikan karakter tidak terlepas dari peran dan fungsi otak manusia tersebut, sehingga pendidikan karakter dapat mengantisipasi terjadinya degradasi moral seseorang yang dapat memicu terjadinya perilaku menyimpang seperti kenakalan, mabuk-mabukan, seks bebas, dan lain sebagainya yang masuk dalam kategori tindakan kurang baik. Peran pendidikan karakter sejatinya sangat penting. Di samping memberikan dampak yang positif bagi seseorang, pendidikan karakter juga mengajarkan nilai-nilai yang dapat diaplikasikan dalam kehidupannya, sehingga nilai-nilai tersebut dapat memberikan pengaruh yang baik dalam perilakunya dan dapat menjauhkannya dari tindakantindakan yang tidak baik.

\section{DAFTAR PUSTAKA}

Al-Qur'an al-Karim.

Amin, D. G. A. (1998). Change your brain, change your life. New York: Three Rivers Press.

Amodio, \& Yee. (2007). Neurocognitive correlate of 
liberalism and conservatism. Nature Neuroscience.

Anita \& Kartowagiran, B. (2019). Karakter religius pada mahasiswa Program Pascasarjana Universitas Negeri Yogyakarta. Jurnal Pendidikan Karakter, 9(2), 163-178. DOI: 10.21831/jpk.v9i2.26838.

Bagus, L. (2005). Kamus filsafat. Jakarta: Gramedia.

Begley, S. (2007). Train your mind, change your brain. New York: Mind and Life Institute.

Budiyanto, M. (2010). Ilmu pendidikan Islam. Yogyakarta: Griya Santri.

Cozolino, L. (2002). The neuroscience of psychotherapy. Building and rebuilding of human brain. New York: W.W.Norton.

Damasio, A. (1994). Descartes error. emotion, reason and the human brain. New York: Avon Books.

Echols, J. M. \& Shadily, H. (2006). Kamus Inggris-Indonesia. Jakarta: Gramedia.

Febrianshari, D., \& Ekowati, D. W. (2018). Analisis nilai-nilai pendidikan karakter dalam pembuatan dompet punch zaman now. Jurnal Pemikiran dan Pengembangan Sekolah Dasar (JP2SD), 6(1), 88-95. DOI: 10.22219/jp2sd.v6i1.5907.

Firmanzah. (2012). Mengatasi masalah narkoba dengan welas asih. Jakarta: Gramedia.

Fitri, A. (2018). Pendidikan karakter prespektif al-Quran hadits. TA'LIM: Jurnal Studi Pendidikan Islam, 1(2), 258287.

DOI: 10.29062/ta'lim.v1i2.952.

Frye, M. et al. (Ed.) (2002).Character education: Informational handbook and guide for support and implementation of the student citizent act of 2001. North Carolina: Public Schools of North Carolina.

Kanai, R., Feilden, T., Frith, C., \& Rees, G. (2011). Political orientations are correlated with brain structure in young adults. Journal of Neuroscience, 21(8), 677-680. DOI: 10.1016/j.cub.2011.03.017.

Kandel., E. (2006). In search of memory. The emergence of a new science of the Mind. New York: Norton Company.

Lickona, T. (1991). Educating for character: How our school can teach respect and responsibility. New York, Toronto, London, Sydney, Aucland: Bantam books.

Majid, A. \& Andayani, D. (2017). Pendidikan karakter perspektif Islam. Bandung: PT Remaja Rosdakarya.

Marimba, A. D. (1989). Pengantar filsafat pendidikan Islam. Bandung: Al Ma'arif.

Marzuki. (2012). Pengintegrasian pendidikan karakter dalam pembelajaran di sekolah. Jurnal Pendidikan Karakter, 2(1) 33-44. DOI: 10.21831/jpk.v0i1.1450.

Marzuki. (2015). Pendidikan karakter Islam. Jakarta: Amzah.

Muslich, M. (2011). Pendidikan karakter menjawab tantangan krisis multidimensional. Jakarta: Bumi Aksara. 
Nashir, H. (2013). Pendidikan karakter berbasis agama dan budaya. Yogyakarta: Multi Presindo.

Pasiak, T. (2010). Pendidikan karakter sebagai pendidikan otak. Jurnal Akrab: Aksara Agar Berdaya, 1(3), 7-15. DOI: 10.26499/jurnalakrab.v1i3.52.

Ramdhani, M. A. (2017). Lingkungan pendidikan dalam implementasi pendidikan karakter. Jurnal Pendidikan UNIGA, 8(1), 28-37. http://journal.uniga.ac.id/index. $\mathrm{php} / \mathrm{JP} /$ article/view/69/70.

Ryan, K. \& Bohlin, K. E. (1999). Building character in schools: Practical ways to bring moral instruction to life. San Francisco: Jossey Bass.

Samani, M. \& Hariyanto. (2011). Konsep dan model pendidikan karakter. Bandung: Remaja Rosdakarya.

Sarjono. (2008). Panduan penulisan skripsi. Yogyakarta: UIN.

Setiawan, A. (2014). Prinsip pendidikan karakter dalam islam: studi komparasi pemikiran al-Ghazali dan Burhanuddin alZarnuji. Dinamika Ilmu, 14(1), $1-12$.

DOI: 10.21093/di.v14i1.4.
Suadu, F. (2018). Manusia unggul neurosains dan al-Qur'an. Jakarta: PT. Penjuru Ilmu Sejati.

Sukmadinata, N. S. (2009). Metode penelitian pendidikan. Bandung: PT. Remaja Rosdakarya.

Suyadi. (2012). Model pendidikan karakter dalam konteks neurosains. Yogyakarta: Prodi PGMI Fakultas Tarbiyah UIN Sunan kalijaga.

Suyadi. (2017). Teori pembelajaran anak usia dini dalam kajian neurosains. Bandung: PT Remaja Rosdakarya.

Tancredi, L. (2005). Hardwire behavioral. What neuroscience reveals about morality. Cambridge University Press.

Tancredi., L. (2005). Hardwire behavioral. What neuroscience reveals about morality. Cambridge University Press.

Timotius, K. H. (2018). Otak dan perilaku. Penerbit Andi.

Zuchdi, D., Muhadjir, N, Prasetya, Z.K., \& Marzuki. (2011). Pendidikan karakter dalam perspektif teori dan praktik. Yogyakarta: UNY Press. 